\title{
Comparative in vitro analysis of inhibition of rhinovirus and influenza virus replication by mucoactive secretolytic agents and plant extracts
}

\author{
Christin Walther ${ }^{\dagger}$, Kristin Döring $^{\dagger}$ and Michaela Schmidtke*
}

\begin{abstract}
Background: Rhinoviruses and influenza viruses cause millions of acute respiratory infections annually. Symptoms of mild acute respiratory infections are commonly treated with over-the-counter products like ambroxol, bromhexine, and $\mathrm{N}$-acetyl cysteine, as well as of thyme and pelargonium extracts today. Because the direct antiviral activity of these over-the-counter products has not been studied in a systematic way, the current study aimed to compare their inhibitory effect against rhinovirus and influenza virus replication in an in vitro setting.

Methods: The cytotoxicity of ambroxol, bromhexine, and N-acetyl cysteine, as well as of thyme and pelargonium extracts was analyzed in Madin Darby canine kidney (MDCK) and HeLa Ohio cells. The antiviral effect of these overthe-counter products was compared by analyzing the dose-dependent inhibition (i) of rhinovirus A2- and B14induced cytopathic effect in HeLa Ohio cells and (ii) of influenza virus A/Hong Kong/68 (subtype H3N2)- and A/ Jena/8178/09 (subtype H1N1, pandemic)-induced cytopathic effect in MDCK cells at non-cytotoxic concentrations. To get insights into the mechanism of action of pelargonium extract against influenza virus, we performed time-ofaddition assays as well as hemagglutination and neuraminidase inhibition assays.

Results: $\mathrm{N}$-acetyl cysteine, thyme and pelargonium extract showed no or only marginal cytotoxicity in MDCK and HeLa Ohio cells in the tested concentration range. The 50\% cytotoxic concentration of ambroxol and bromhexine was 51.85 and $61.24 \mu \mathrm{M}$, respectively. No anti-rhinoviral activity was detected at non-cytotoxic concentrations in this in vitro study setting. Ambroxol, bromhexine, and $\mathrm{N}$-acetyl cysteine inhibited the influenza virus-induced cytopathic effect in MDCK cells no or less than 50\%. In contrast, a dose-dependent anti-influenza virus activity of thyme and pelargonium extracts was demonstrated. The time-of addition assays revealed an inhibition of early and late steps of influenza virus replication by pelargonium extract whereas zanamivir acted on late steps only. The proven block of viral neuraminidase activity might explain the inhibition of influenza virus replication when added after viral adsorption.
\end{abstract}

(Continued on next page)

\footnotetext{
* Correspondence: michaela.schmidtke@med.uni-jena.de

${ }^{\dagger}$ Christin Walther and Kristin Döring shared first authorship based on equal contribution

Department Medical Microbiology, Section Experimental Virology, Jena

University Hospital, Hans-Knöll-Str. 2, D-07745 Jena, Germany
}

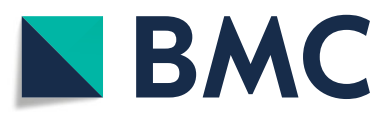

(c) The Author(s). 2020 Open Access This article is licensed under a Creative Commons Attribution 4.0 International License, which permits use, sharing, adaptation, distribution and reproduction in any medium or format, as long as you give appropriate credit to the original author(s) and the source, provide a link to the Creative Commons licence, and indicate if changes were made. The images or other third party material in this article are included in the article's Creative Commons licence, unless indicated otherwise in a credit line to the material. If material is not included in the article's Creative Commons licence and your intended use is not permitted by statutory regulation or exceeds the permitted use, you will need to obtain permission directly from the copyright holder. To view a copy of this licence, visit http://creativecommons.org/licenses/by/4.0/. The Creative Commons Public Domain Dedication waiver (http://creativecommons.org/publicdomain/zero/1.0/) applies to the data made available in this article, unless otherwise stated in a credit line to the data. 
(Continued from previous page)

Conclusion: The study results indicate a distinct inhibition of influenza A virus replication by thyme and pelargonium extract which might contribute to the beneficial effects of these plant extracts on acute respiratory infections symptoms.

Keywords: Acute respiratory infection, Virus, Natural products, Over-the-counter medication, Ambroxol, Bromhexine, $\mathrm{N}$-acetyl cysteine, Thyme, Pelargonium, Antiviral, Mechanism

\section{Background}

Acute respiratory infections affect the upper and/or lower respiratory tract and account for the majority of infectious diseases worldwide. Due to the high number of hours of school and work absence, primary care, hospitalization, medications etc. acute respiratory infections have a huge medical and economic impact. Severe infections of the lower respiratory tract even represent the fourth most common reason of death worldwide [1].

Acute respiratory infections are commonly caused by viruses [2] whereat new viruses can emerge and cause pandemics as seen for example for influenza A viruses of subtype H1N1 in 2009 and for coronaviruses in 2019 [3]. In particular, rhinoviruses, influenza viruses, and coronaviruses are frequently diagnosed in acute respiratory infections with mild as well as severe respiratory symptoms, including acute lung injury $[4,5]$. Annual influenza epidemics are estimated to result in about 3 to 5 million cases of severe illness, and about 290,000 to 650 , 000 respiratory deaths [6]. Measures of prevention and treatment of rhinovirus and coronavirus infections do not exist, albeit several virus proteins e. g. viral capsid, protease, and polymerase proteins have been identified as valid targets of inhibitors [7-9]. Even though influenza vaccines do exist, they are suboptimal applied [1013]. The arsenal of drugs for treatment of influenza is limited. It includes M2 ion channel blockers (amantadine and rimantadine), neuraminidase inhibitors (oseltamivir, zanamivir, laninamivir, and peramivir), and polymerase inhibitors (favipiravir and baloxavir) today $[14,15]$. Moreover, there is a permanent risk of emergence of drug-resistant influenza viruses due to the high genetic variability based on point mutations and gene reassortment [16]. For example, the two M2 ion channel blockers are not recommended for use in monotherapy because the circulating influenza A viruses are resistant today [6]. Of note, ion channel blockers do generally not act against influenza $B$ viruses due to structural differences in the viral target [17]. According to recommendations of the World Health Organization, "Patients with severe or progressive clinical illness associated with suspected or confirmed influenza virus infection (i.e. clinical syndromes of pneumonia, sepsis or exacerbation of chronic underling diseases) should be treated with antiviral drugs as soon as possible." [6]. Ideally treatment should be started within $48 \mathrm{~h}$ following symptom onset to maximize therapeutic benefits but, drug administration should also be considered in patients presenting later in the course of illness [6].

The World Health Organization further recommends that influenza patients who are not in a high-risk group "should be managed with symptomatic treatment and are advised, if symptomatic, to stay home in order to minimize the risk of infecting others in the community. Treatment focuses on relieving symptoms of influenza such as fever." [6]. In fact, the management of upper and lower respiratory tract infections often relies on the use of self-medicated over-the-counter medicines [18]. According to this European study analyzing the medication use in primary care patients with lower respiratory tract infections, $55.4 \%$ of patients self-medicated before consultation and $21.5 \%$ after consultation. Mucolytic agents were amongst the most frequently used self-medications. Mucolytic agents like ambroxol (a metabolite of bromhexine), bromhexine, and $\mathrm{N}$-acetyl cysteine are also widely used in the therapy of chronic obstructive pulmonary disease (reduction of frequency and duration of exacerbations), bronchitis and sinusitis [19]. The mucolytic, anti-inflammatory and anti-oxidant properties of mucolytic agents have been shown to contribute to symptom relief $[19,20]$ but further research is needed to prove their efficacy $[18,19]$. Furthermore, thyme and pelargonium extract are frequently used for symptomatic treatment of acute respiratory infections [21-23].

The antiviral potential of over-the-counter medicines has been studied sporadically. Few studies were performed with ambroxol [24, 25], N-acetyl cysteine [26-29], and pelargonium extracts [30-32] in vitro and/or in vivo. The results are hard to compare because, in part, very high agent concentrations, different experimental conditions (e. g. cell lines or primary cells, different treatment schedules, infections dose, and controls), and study parameters (e.g. lethality and time of symptom release) were applied. Albeit the study results show beneficial treatment effects in vitro and in vivo, it is difficult to draw conclusions on the effects of most of these self-medications on rhinovirus and/or anti-influenza virus replication. Although in vitro experiments cannot mimic the multifactorial and very complex in vivo situation and have only a limited predictive value for the clinical setting, antiviral effects shown 
in vitro can help to explain treatment success seen in vivo or in a clinical setting.

In this study, we aimed to comparatively analyze the effect of ambroxol, bromhexine, $\mathrm{N}$-acetylcysteine, thyme, and pelargonium extract on the replication of rhinoviruses and influenza A viruses at non-cytotoxic micromolar concentrations in vitro. The well-known inhibitors pleconaril and zanamivir were used to validate the antiviral assays with rhinoviruses and influenza A viruses, respectively. To ensure the selectivity of the antiviral effect, we analyzed the cytotoxicity of all extracts and compounds in the cell lines used for antiviral studies. Moreover, we performed time-of-addition studies with the anti-influenza virus-active pelargonium extract to get insights into its mechanism of action.

\section{Methods}

\section{Reference compounds and test items}

As there are no drugs to treat rhinovirus infections, we applied pleconaril, a capsid-binding inhibitor with well-known antirhinoviral activity to validate the antiviral assays. The sensitivity of rhinoviruses to pleconaril has been determined in previous studies [33, 34]. For influenza A viruses the drug zanamivir (GlaxoSmithKline) was used as reference compound. Zanamivir is an approved, direct anti-influenza virus-acting drug targeting the viral neuraminidase [35]. The zanamivir sensitivity of the used influenza A viruses was known [36, 37]. Stock solutions of pleconaril and zanamivir $(10,000 \mu \mathrm{M})$ were prepared in dimethyl sulfoxide and bi-distilled water, respectively. The highest dimethyl sulfoxide concentration in the test was $0.05 \%$.

The cytotoxic and antiviral activities of ambroxol and bromhexine hydrochloride (Boehringer Ingelheim Pharma GmbH \& Co KG, Ingelheim, Germany), N-acetylcysteine (SIGMA-Aldrich Chemie GmbH, Schnelldorf, Germany), fluid thyme extract (R\&R Extrakte $\mathrm{GmbH}$; Cologne, Germany), pelargonium extract (A. Nattermann \& Cie. $\mathrm{GmbH}$; Cologne, Germany) were compared in this study. According to the supplier information, the fluid thyme extract consists $31.2 \%$ ethanol and $0.06 \%(\mathrm{v} / \mathrm{v})$ thymol (phenol calculated as thymol) and pelargonium root powder extract $30.2 \%(\mathrm{~m} / \mathrm{m})$ polyphenols and $0.5 \%(\mathrm{~m} / \mathrm{m})$ umckalin. The thyme extract was used as provided. Stock solutions of the other test items were prepared in dimethyl sulfoxide in the following concentrations: $10,000 \mu \mathrm{g} / \mathrm{mL}$ of pelargonium extract or $10,000 \mu \mathrm{M}$ for ambroxol, bromhexine, and $\mathrm{N}$-acetylcysteine.

Working solutions of the reference compounds and test items were done in the test medium described in the following paragraph.

\section{Cell lines and virus strains}

HeLa Ohio (human cervix carcinoma; Flow Labs; USA) and Madin Darby canine Kidney (MDCK; Friedrich Löffler Institute; Germany) cells allow the determination of cytotoxicity as well as antiviral activity of compounds and extracts against rhinoviruses and influenza A viruses, respectively [38]. The growth medium for propagation of HeLa Ohio cells contained Eagle's minimal essential medium, supplemented with $5 \%$ fetal calf serum, $2 \mathrm{mM} \mathrm{L-glutamine,} \mathrm{and} 1 \%$ nonessential amino acids. Eagle's minimal essential medium with $10 \%$ fetal calf serum, $2 \mathrm{mML}$-glutamine, and $1 \%$ nonessential amino acids was used to propagate MDCK cells.

The Eagle's minimal essential medium for antirhinoviral tests (test medium) in HeLa Ohio cells was supplemented with $2 \%$ fetal calf serum only. The antiviral tests with influenza A viruses were performed in MDCK cells with Eagle's minimal essential medium supplemented with $2.3 \%$ sodium bicarbonate, $2 \mu \mathrm{g} / \mathrm{mL}$ trypsin, $2 \mathrm{mM}$ L-glutamine, and $1 \%$ nonessential amino acids (test medium).

Viruses included in this study were rhinovirus A2 (Institute of Biochemistry, University, Vienna, AUT), rhinovirus B14 (Charité, Berlin, Germany), the H3N2 influenza virus A/Hong Kong/68 (Schaper and Brümmer, Salzgitter, Germany), and the A(H1N1)pdm09 influenza virus A/Jena/8178/09 (isolated and kindly provided by Andy Krumbholz [37]). Rhinoviruses and influenza A viruses were grown and titrated in HeLa Ohio and MDCK cells, respectively. The determined virus titers of rhinovirus A2, rhinovirus B14, influenza virus A/Hong Kong/ 68 , and influenza virus $\mathrm{A} / \mathrm{Jena} / 8178 / 09$ were $6.3 \times 10^{6}$ $\mathrm{TCID}_{50} / \mathrm{mL}, 2.0 \times 10^{6} \mathrm{TCID}_{50} / \mathrm{mL}, 2.0 \times 10^{7} \mathrm{TCID}_{50} / \mathrm{mL}$, and $6.3 \times 10^{7} \mathrm{TCID}_{50} / \mathrm{mL}$, respectively. Aliquots of the virus working passages were stored at $-80^{\circ} \mathrm{C}$ until use.

\section{Cytotoxicity determination}

HeLa Ohio and MDCK cells were seeded at $1.6 \times 10^{4}$ and $2.3 \times 10^{4}$ cells/well in $100 \mu \mathrm{L}$ growth medium in 96 well flat-bottomed microtiter plates, respectively. The cytotoxicity of the test compounds and extracts was determined on two-day-old confluent cell monolayers grown in the internal 60 wells of a microtiter plate $(5 \%$ carbon dioxide, $37^{\circ} \mathrm{C}$ ). After removal of the growth medium, $50 \mu \mathrm{L}$ of test medium and eight half-log dilutions of the reference compounds pleconaril or zanamivir, or eight half-log dilutions of test items in test medium (each concentration in duplicates) were added. The concentration range of reference compounds applied to cytotoxicity assays was $0.0316-100 \mu \mathrm{M}$. The concentration range of test items was $0.0003-0.5 \% \mathrm{v} / \mathrm{v}$ for thyme extract, $0.0316-100 \mu \mathrm{g} / \mathrm{mL}$ for pelargonium extract, and $0.0316-100 \mu \mathrm{M}$ for ambroxol, bromhexine, and $\mathrm{N}$-acetylcysteine. Six cell control wells were 
incubated with $100 \mu \mathrm{L}$ test medium. After $72 \mathrm{~h}$ of incubation at $37^{\circ} \mathrm{C}$ in $5 \%$ carbon dioxide atmosphere, the Dynex Immuno Assay System (Guernsey, UK), developed for automated ELISA techniques, was applied to gently wash, stain, measure, and analyze the viability of the cell monolayers based on optical density determination [39]. After aspiration of supernatant, cell monolayers were washed three times with $300 \mu \mathrm{L}$ physiological phosphate-buffered saline to remove death cells. The remaining cells were fixed and stained with $50 \mu \mathrm{L}$ of $0.07 \%$ crystal violet $(\mathrm{w} / \mathrm{v}), 20 \%$ ethanol, $3 \%$ formalin solution in water for $10 \mathrm{~min}$. Six washings with $300 \mu \mathrm{L}$ of water followed to remove excess stain. Before measuring the optical density, we solubilized the crystal violet by adding $100 \mu \mathrm{L}$ lysis buffer $(0.898 \mathrm{~g}$ of sodium citrate and $1.25 \mathrm{~mL}$ of $1 \mathrm{~N} \mathrm{HCl}$ in $98.05 \mathrm{~mL} 47.5 \%$ ethanol) for $20 \mathrm{~min}$. The absorbances were red at two wavelengths (550 and $690 \mathrm{~nm}$ ). Cell viability in a well was defined as the percentage of the mean value of optical density resulting from the six cell controls, which was set $100 \%$ cell viability. The inhibitor concentration that reduces the mean value of optical density determined for cell controls by half is called $50 \%$ cytotoxic concentration $\left(\mathrm{CC}_{50}\right)$. A minimum of three independent experiments were performed.

\section{Antiviral assays}

Replication of the applied rhinoviruses and influenza viruses causes morphological changes and cell death (called cytopathic effect; CPE) of infected HeLa Ohio and MDCK cells, respectively. The CPE can be quantified after staining the cells with crystal violet and dye elution by optical density measurement as described before [34, 39]. The ability of compounds or extracts to protect cells from the virus-induced CPE can be analyzed using CPE inhibitory assays. Seeding and growth of MDCK cells was done similarly to the cytotoxicity assay with some modifications. Thus, HeLa Ohio cells were incubated for one day only. In addition, we washed the MDCK cells once with $100 \mu \mathrm{L}$ test medium to remove the fetal calf serum hampering the influenza virus replication immediately before beginning with the CPE inhibitory assay.

$\mathrm{CPE}$ inhibitory assays started with the aspiration of the cell growth medium (rhinoviruses) or test medium (influenza viruses). Immediately thereafter, we added $50 \mu \mathrm{L}$ of test medium (mock-treatment of cell and virus controls; each $n=6$ ) or eight half-log dilutions of reference compounds or test items in test medium. Then we inoculated $50 \mu \mathrm{L}$ of a virus suspension consisting a certain multiplicity of infection $\left(\mathrm{MOI}=\mathrm{TCID}_{50}\right.$ of virus used for infection in a well/number of cells present in that well) of the respective test virus in $50 \mu \mathrm{L}$ of the test medium to the cell monolayers. The MOI of rhinovirus A2, rhinovirus B14, influenza virus $\mathrm{A} / \mathrm{Hong}$ Kong/68, and influenza virus $\mathrm{A} / \mathrm{Jena} / 8178 / 09$ was adjusted to 0.03 , $0.01,0.008$, and 0.005 , respectively. The concentration range of reference compounds (pleconaril or zanamivir) applied to the CPE inhibitory assays was $0.0003-1 \mu \mathrm{M}$. The concentration range of test items applied to test was $0.0003-0.5 \% \mathrm{v} / \mathrm{v}$ for thyme extract, $0.0316-100 \mu \mathrm{g} /$ $\mathrm{mL}$ for pelargonium extract, and $0.0316-100 \mu \mathrm{M}$ for ambroxol, bromhexine, and N-acetylcysteine. Six wells of non-infected and six wells of infected cells (both mock-treated with test medium) served as cell and virus control, respectively, on each plate.

Plates were incubated at $37^{\circ} \mathrm{C}$ in a humidified atmosphere with $5 \%$ carbon dioxide for $48 \mathrm{~h}$ (influenza A viruses) or $72 \mathrm{~h}$ (rhinovirus A2), or at $33^{\circ} \mathrm{C}$ for $72 \mathrm{~h}$ (rhinovirus B14) until a complete CPE was visible in the six mock-treated virus control wells under a light microscope. Thereafter, the viable cells were fixed and stained with the Dynex Immuno Assay System (Guernsey, UK). We described the details in the paragraph cytotoxicity determination. Crystal violet elution and optical density determination were also described there. The percentage of CPE inhibition by the test compounds was calculated according to Pauwels et al. [40] using the following equation: [(optical density measured with a given concentration of the test compound or extract in virusinfected cells - mean optical density of six virus controls) / (mean optical density of six cell controls - mean optical density of six virus controls)] $\times 100 \%$. A $100 \%$ CPE inhibition means that the optical density of virusinfected, inhibitor-treated cells corresponded with the mean optical density of the six cell controls which was set $100 \%$ cell viability. Hence, $100 \%$ of virus-infected, inhibitor-treated cells were viable. At least three independent experiments were performed.

\section{Time-of-addition assays with pelargonium extract}

We analyzed the inhibitory activity of pelargonium extract $(50 \mu \mathrm{g} / \mathrm{mL}$; triplicates) on different steps of the replication cycle of influenza virus A/Hong Kong/68 with plaque-reduction assays in MDCK cells grown in 12-well cell culture plates. We added pelargonium extract for different times and at different temperatures as described previously for another inhibitor [41]. Triplicates of mock-treated, not infected (cell control) and mocktreated, infected MDCK cells (virus control), and zanamivir-treated ( $1 \mu \mathrm{M}$; reference inhibitor), infected MDCK cells were included on each cell culture.

We compared the inhibitory effect of pelargonium extract and zanamivir using the following times and temperatures:

a) Pre-treatment of cells. MDCK cells were treated with zanamivir or pelargonium extract for $1 \mathrm{~h}$ at 
$37^{\circ} \mathrm{C}$. Zanamivir and the extract were washed out before virus inoculation.

b) Pre-treatment of virus. Virus suspension was incubated with zanamivir or pelargonium extract for $1 \mathrm{~h}$ at $37^{\circ} \mathrm{C}$ and subsequently diluted to noneffective inhibitor concentrations $(1: 10,000)$ prior inoculation to MDCK cells.

c) During adsorption. Zanamivir or pelargonium extract were added during virus adsorption at $4{ }^{\circ} \mathrm{C}$ for $2 \mathrm{~h}$, a temperature and time allowing viruses to attach to MDCK cells but not to replicate.

d) After adsorption: Virus was allowed to attach to MDCK cells as in c) but without zanamivir or pelargonium extract. After aspirating non-adsorbed virus, we added zanamivir or pelargonium extract with the agar-overlay to the virus-infected MDCK cells for $72 \mathrm{~h}$.

e) During adsorption till end. Virus attached to MDCK cells as in c). After washing away nonadsorbed virus, we added zanamivir or pelargonium extract with the agar-overlay to the virus-infected MDCK cells for $72 \mathrm{~h}$.

At the end of the incubation time, we added a crystal violet solution $(0.25 \%$ crystal violet $(\mathrm{w} / \mathrm{v}), 0.5 \%$ ethanol, $4 \%$ formalin solution in water; $300 \mu \mathrm{L} /$ well) for cell fixation, virus inactivation, and staining overnight. After removal of the agar overlay and washing of MDCK cell monolayers with tap water for removal of excess stain, we counted the plaques over a light box. We calculated the percentage of plaque production in zanamivir- or pelargonium extract-treated virus-infected MDCK cells by setting the mean number of plaques of the 3 virus controls to $100 \%$.

\section{Hemagglutination and neuraminidase inhibition assay with human erythrocytes}

We used a standard protocol developed for quantification of influenza virus-specific antibodies [42] to evaluate the effect of pelargonium extract on hemagglutination. Briefly, $25 \mu \mathrm{L}$ of an influenza virus $\mathrm{A} / \mathrm{Jena} / 8178 / 09$ suspension consisting 4 hemagglutination units was added to an equal volume of phosphate-buffered saline (hemagglutination control; $n=8$ ), serial half-logarithmic dilutions of zanamivir (duplicates; maximum test concentration: $1 \mu \mathrm{M}$ ) or pelargonium extract (duplicates; maximum test concentration: $100 \mu \mathrm{g} / \mathrm{mL}$ ) in a U-bottom 96-well polystyrene microplate. The negative control (no hemagglutination) consists only $50 \mu \mathrm{L}$ phosphate-buffered saline $(n=8)$. We also tested the hemagglutination capacity of zanamivir or pelargonium extract dilutions in the absence of viral antigen to exclude unwanted effects e.g. erythrocyte lysis or induction of hemagglutination on the assay readout. We added $50 \mu \mathrm{L}$ of a $1 \%$ human erythrocytes solution to each well of the microplate. After a two-hour incubation at $4{ }^{\circ} \mathrm{C}$, we recorded the lowest compound concentration that induces hemagglutination or inhibits virus-mediated hemagglutination (minimum hemagglutination or hemagglutination inhibitory concentration, respectively).

Thereafter, we incubated the assays at $37^{\circ} \mathrm{C}$ for further $24 \mathrm{~h}$ allowing viral neuraminidase activation [43]. The activated viral neuraminidase abrogates the virusmediated hemagglutination in absence of inhibitors (hemagglutination control) or in the presence of ineffective inhibitor concentrations. Neuraminidase inhibitors prevent this abrogation of virus-mediated hemagglutination. We recorded the lowest compound concentration that inhibits the neuraminidase activity as the minimum neuraminidase inhibitory concentration and repeated the assay once for result confirmation.

\section{Data analysis}

The 50\% cytotoxic and inhibitory concentrations $\left(\mathrm{CC}_{50}\right.$ and $\mathrm{IC}_{50}$ values) were calculated from doseresponse curves. Linear regression analysis using Microsoft Excel 2010 was applied in the linear scaled dose-dependent sample concentrations. We calculated means and standard deviations of the calculated 50\% cytotoxic and the 50\% inhibitory concentrations using Microsoft Excel 2010.

\section{Results}

Cytotoxicity in HeLa Ohio cells and anti-rhinovirus activity The cytotoxicity of test items for HeLa Ohio cells was quantified using a crystal violet staining procedure at day three after compound addition. Table 1 and Fig. 1 summarize the results. Only non-cytotoxic concentrations $(\geq 90 \%$ viability as compared to the mean optical density value of six cell controls which was set $100 \%$ cell viability) were used to assess antiviral activity to avoid an impairment of virus growth due to cytotoxic effects of the test items.

The control compound pleconaril exerted a marked dose-dependent cytotoxic effect in HeLa Ohio cells when applied at concentrations higher than $10 \mu \mathrm{M}$ (Fig. 1a). However, pleconaril dose-dependently inhibited the rhinovirus A2- and rhinovirus B14-induced $\mathrm{CPE}$ at low micromolar concentrations that were well tolerated by HeLa Ohio cells (Fig. 1a, Table 1). Thus, the $\mathrm{CC}_{50} / \mathrm{IC}_{50}$ ratio indicating the selectivity of pleconaril activity was $>3500$.

With the exception of thyme extract, all test items were well tolerated in Hela Ohio cells. $\mathrm{N}$-acetylcysteine was non-cytotoxic in the tested concentration range (Table 1). However, in contrast to pleconaril and as seen in Fig. 1b-f, none of the tested over-the-counter products reduced the rhinovirus A2- and rhinovirus B14induced $\mathrm{CPE}$ at concentrations that are non-cytotoxic 
Table 1 Cytotoxicity and antiviral activity of test items and control compounds

\begin{tabular}{|c|c|c|c|c|c|c|c|c|c|c|c|c|c|c|c|}
\hline \multirow{4}{*}{$\begin{array}{l}\text { Compounds } \\
\text { /Extracts }\end{array}$} & \multirow[t]{4}{*}{ Units } & \multirow{2}{*}{\multicolumn{4}{|c|}{$\begin{array}{l}50 \% \text { Cytotoxic } \\
\text { concentration in }\end{array}$}} & \multicolumn{8}{|c|}{$50 \%$ Inhibitory concentration against } & \multirow{2}{*}{\multicolumn{2}{|c|}{$\frac{\text { Selectivity index against }}{\text { Influenza A viruses }}$}} \\
\hline & & & & & & \multicolumn{4}{|c|}{ Rhinoviruses } & \multicolumn{4}{|c|}{ Influenza A viruses } & & \\
\hline & & \multicolumn{2}{|c|}{ HeLa cells } & \multicolumn{2}{|c|}{ MDCK cells } & \multicolumn{2}{|l|}{ A2 } & \multicolumn{2}{|l|}{ B14 } & \multicolumn{2}{|c|}{ Jena/8178 } & \multicolumn{2}{|l|}{ HK/68 } & \multirow[t]{2}{*}{ Jena/8178 } & \multirow[t]{2}{*}{$\mathrm{HK} / 68$} \\
\hline & & Mean & SD & Mean & SD & Mean & SD & Mean & SD & Mean & SD & Mean & SD & & \\
\hline Pleconaril & $\mu \mathrm{M}$ & 28.75 & 8.06 & n.d. & & 0.008 & 0.003 & 0.025 & 0.009 & n.d. & & n.d. & & & \\
\hline Zanamivir & $\mu \mathrm{M}$ & n.d. & & $>100^{a}$ & & n.d. & & n.d. & & 0.007 & 0.004 & 0.008 & 0.003 & $>14,285$ & $>12,500$ \\
\hline Bromhexine & $\mu \mathrm{M}$ & 51.85 & 9.80 & 51.29 & 9.08 & n.a. & & n.a. & & n.a. & & n.a. & & & \\
\hline Ambroxol & $\mu \mathrm{M}$ & 61.24 & 42.03 & $>100^{a}$ & & n.a. & & n.a. & & n.a. & & n.a. & & & \\
\hline $\mathrm{N}$-acetylcysteine & $\mu \mathrm{M}$ & $>100^{a}$ & & $>100^{a}$ & & n.a. & & n.a. & & n.a. & & n.a. & & & \\
\hline Thyme extract & $\% \mathrm{v} / \mathrm{v}$ & $>0.5^{\mathrm{a}}$ & & 0.32 & 0.07 & n.a. & & n.a. & & 0.03 & 0.01 & 0.03 & 0.00 & 11 & 11 \\
\hline Pelargonium extract & $\mu \mathrm{g} / \mathrm{ml}$ & $>100^{\mathrm{a}}$ & & $>100^{a}$ & & n.a. & & n.a. & & 7.80 & 2.55 & 11.67 & 6.03 & $>13$ & $>9$ \\
\hline
\end{tabular}

Means and standard deviation (SD) of the calculated 50\% cytotoxic and the $50 \%$ inhibitory concentrations are shown n.d not determined, n.a not active up to the maximum non-cytotoxic concentration

${ }^{a}$ more than $50 \%$ viability at the maximum tested concentration. Therefore, the $50 \%$ cytotoxic concentration is assumed to be higher than $100 \mu \mathrm{g} / \mathrm{ml}, 100 \mu \mathrm{M}$, or $0.5 \% \mathrm{v} / \mathrm{v}$

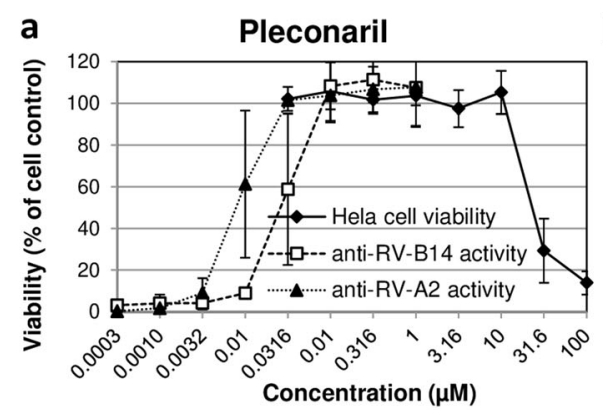

C
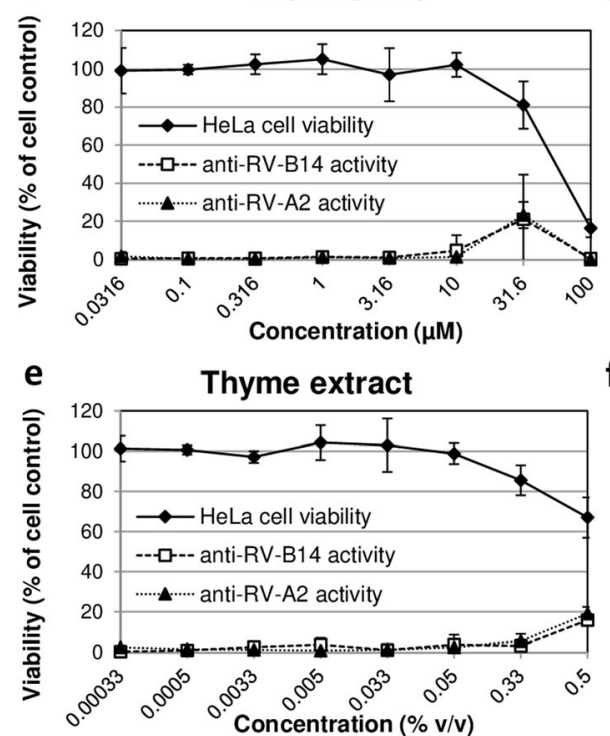

b

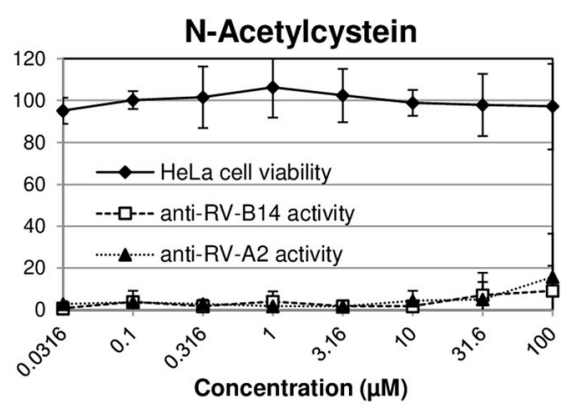

d

Ambroxol

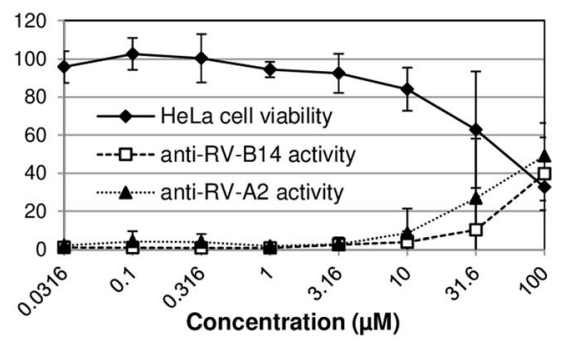

f

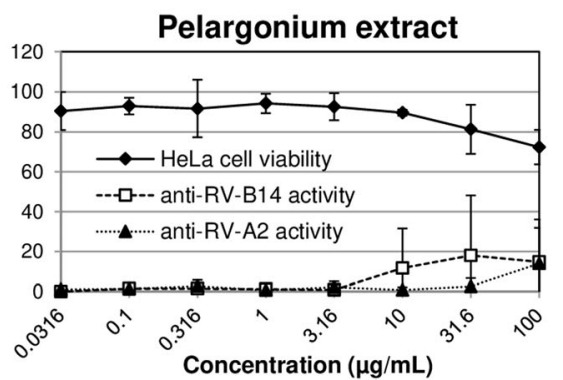

Fig. 1 Dose-dependent cytotoxicity and anti-rhinovirus activity of pleconaril and test items in HeLa Ohio cells. The cytotoxicity and anti-influenza activity of zanamivir (a), N-acetylcystein (b), bromhexine (c), ambroxol (d), thyme extract (e), and pelargonium extract (f) was analyzed in MDCK cells. The percentage of cell viability was used as readout for analyzing the cytotoxic and antiviral effects. Cell viability was evaluated as the percentage of the mean value of optical density resulting from 6 cell controls, which was set 100\%. Cytotoxic compounds have the potential to reduce cell viability. Influenza virus A/Hong Kong/68 (HK/68) and influenza virus A/Jena/8178/09 (Jena/8178) were included in the antiviral studies. Replication of both viruses results in a complete cytopathic effect of untreated MDCK cells thereby also reducing cell viability. Effective compound/extract treatment enhances the percentage of cell viability. Means and standard deviations of at least three independent experiments are shown 
for HeLa Ohio cells. A slight inhibition of rhinovirusinduced CPE was seen at concentrations affecting also cell viability. Thus, we cannot exclude an unspecific inhibition of viral replication mediated by the measured cytotoxic effect.

\section{Cytotoxicity in MDCK cells and anti-influenza a virus activity}

The control compound zanamivir was well tolerated by MDCK cells (Fig. 2a). Zanamivir inhibited the influenza virus $\mathrm{A} /$ Hong Kong/68- and influenza virus A/Jena/8178/ 09-induced CPE at nano- and micromolar concentrations in a dose-dependent manner as expected (Fig. 2a, Table 1).

As seen in Table 1, Fig. $2 b$ and $d, N$-acetylcysteine and ambroxol did not show any effect on influenza virus $\mathrm{A} / \mathrm{Hong}$ Kong/68 and influenza virus $\mathrm{A} /$ Jena/ $8178 / 09$ at non-cytotoxic concentrations (MDCK cell viability $>90 \%)$..

Bromhexine was cytotoxic at $100 \mu \mathrm{M}$ (Fig. 2c). At $31.6 \mu \mathrm{M}$ the influenza virus $\mathrm{A} / \mathrm{Hong} \mathrm{Kong} / 68$-induced CPE was reduced by $30 \%$.

Thyme extract was cytotoxic at the maximum tested concentration of $0.5 \% \mathrm{v} / \mathrm{v}$ (Fig. 2e). At lower, noncytotoxic concentrations, the thyme extract dosedependently decreased the influenza virus A/Hong Kong/68- and influenza virus A/Jena/8178/09-induced $\mathrm{CPE}$ indicating an antiviral activity.

The pelargonium extract exerted the strongest dosedependent anti-influenza virus effect compared to the other 4 tested over-the-counter products. It showed $\mathrm{IC}_{50}$

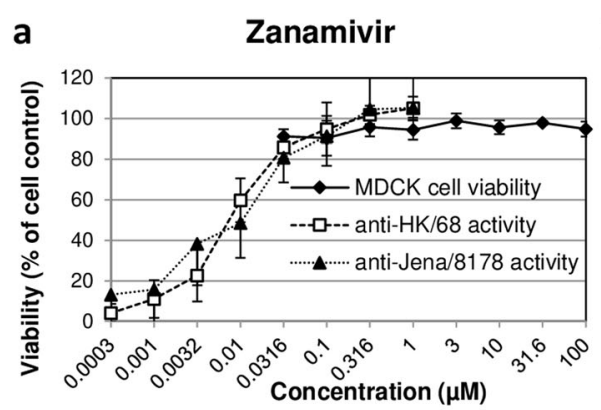

C
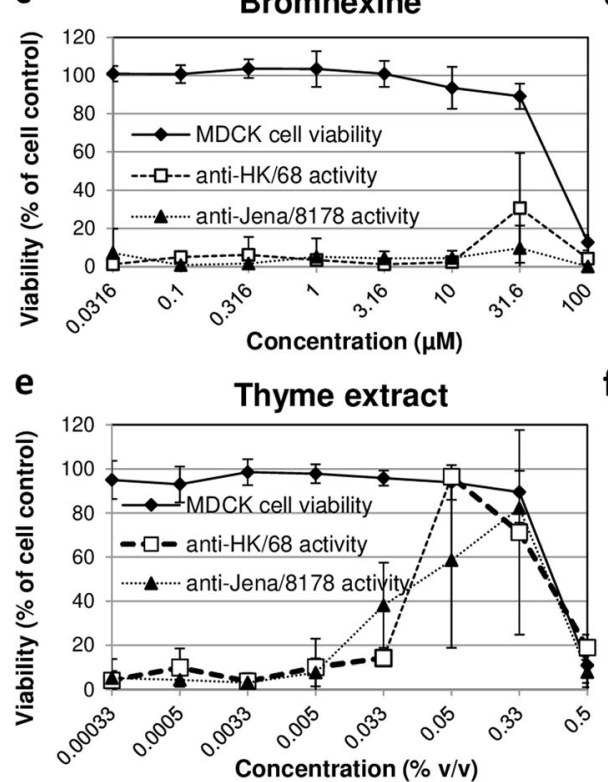

b $\mathrm{N}$-Acetylcystein

b

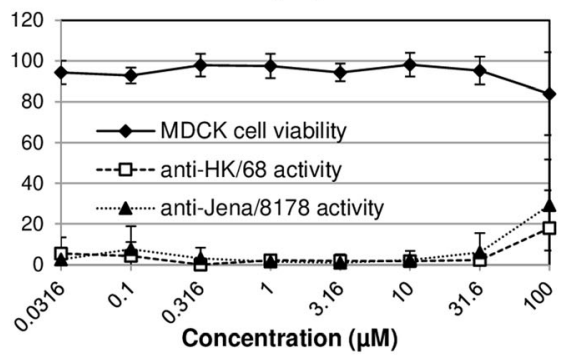

d

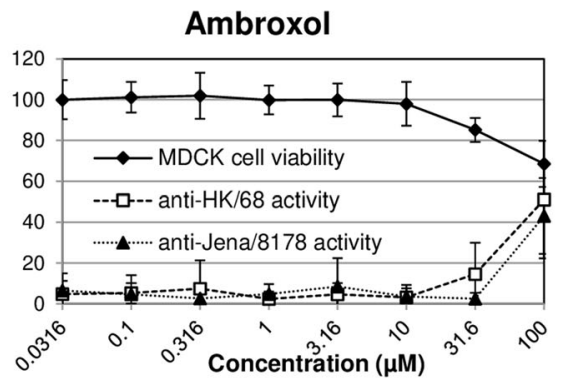

f

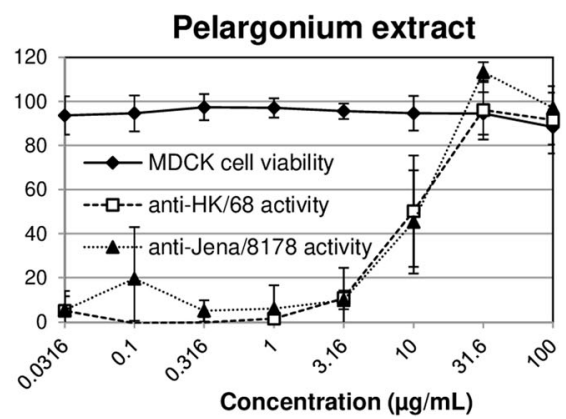

Fig. 2 Dose-dependent cytotoxicity and anti-influenza virus activity of zanamivir and test items in MDCK cells. The cytotoxicity and anti-influenza virus activity of zanamivir (a), N-acetylcystein (b), bromhexine (c), ambroxol (d), thyme extract (e), and pelargonium extract (f) was analyzed in MDCK cells. The percentage of cell viability was used as readout for analyzing cytotoxic and antiviral effects. Cell viability was evaluated as the percentage of the mean value of optical density resulting from 6 cell controls, which was set 100\%. Cytotoxic compounds have the potential to reduce cell viability. Influenza virus A/Hong Kong/68 (HK/68) and influenza virus A/Jena/8178/09 (Jena/8178) were included in the antiviral studies. Replication of both viruses results in a complete cytopathic effect of untreated MDCK cells thereby reducing cell viability. Effective compound/extract treatment enhances the percentage of cell viability. Means and standard deviations of at least three independent experiments are shown 
values of approximately $10 \mu \mathrm{M}$ against both, influenza virus $\mathrm{A} /$ Hong Kong/68- and influenza virus $\mathrm{A} / \mathrm{Jena} /$ $8178 / 09$ and was non-cytotoxic at the tested concentrations (Table 1, Fig. 2f).

In summary, there was no antiviral activity against rhinovirus A2 and rhinovirus B14 at non-cytotoxic concentrations. Thyme and pelargonium extract inhibited the influenza virus-induced cytopathic effect in MDCK cells, whereas the other test items did not have antiviral activity.

Treatment with pelargonium extract before, during, and after virus inoculation to MDCK cells inhibits plaque production of influenza virus $\mathrm{A} / \mathrm{Hong}$ Kong/68

We performed time-of-addition assays to see the effect of pelargonium extract $(50 \mu \mathrm{g} / \mathrm{mL})$ on different steps of the viral life cycle. Therefore, we added pelargonium extract at different time points and temperatures before, during (adsorption), and after influenza virus A/Hong Kong/68 inoculation to MDCK cells in plaque-reduction assays. Zanamivir $(1 \mu \mathrm{M})$ was included as reference.

As expected, the reference compound zanamivir did not prevent the replication of influenza virus A/Hong Kong/68 when added before infection or during adsorption but completely blocked plaque production when added after viral adsorption as well as during and after viral adsorption (Fig. 3). In contrast, we observed a nearly complete inhibition of plaque production after treating MDCK cells or influenza virus A/Hong Kong/68 with pelargonium extract before infection (Fig. 3, pretreatment of cells or virus). Pelargonium extract also blocked the plaque production when treatment occurred during virus adsorption, after adsorption, and both during adsorption and after adsorption (Fig. 3). Thus, pelargonium extract blocked various steps of the viral life cycle.

\section{Pelargonium extract affects hemagglutination and inhibits the viral neuraminidase activity}

To see whether pelargonium extract binding to the viral envelope or cell surface impairs the binding of the viral hemagglutinin to sialic acid-consisting receptors on the cells surface (adsorption) and/or the function of the neuraminidase, we performed hemagglutination assays with influenza virus A/8178/09 and human erythrocytes. The neuraminidase inhibitor zanamivir was included as control.

There was no hemagglutination in the absence of virus (Fig. 4a; Co1). Influenza virus A/8178/09 mediated the hemagglutination of the human erythrocytes (Fig. 4a; Co2). Incubation of pelargonium extract with human erythrocytes also caused hemagglutination at 3.16 and $10 \mu \mathrm{g} / \mathrm{mL}$ in the absence of influenza virus, (Fig. 4a). Higher concentrations of pelargonium extract prevented influenza virus-mediated

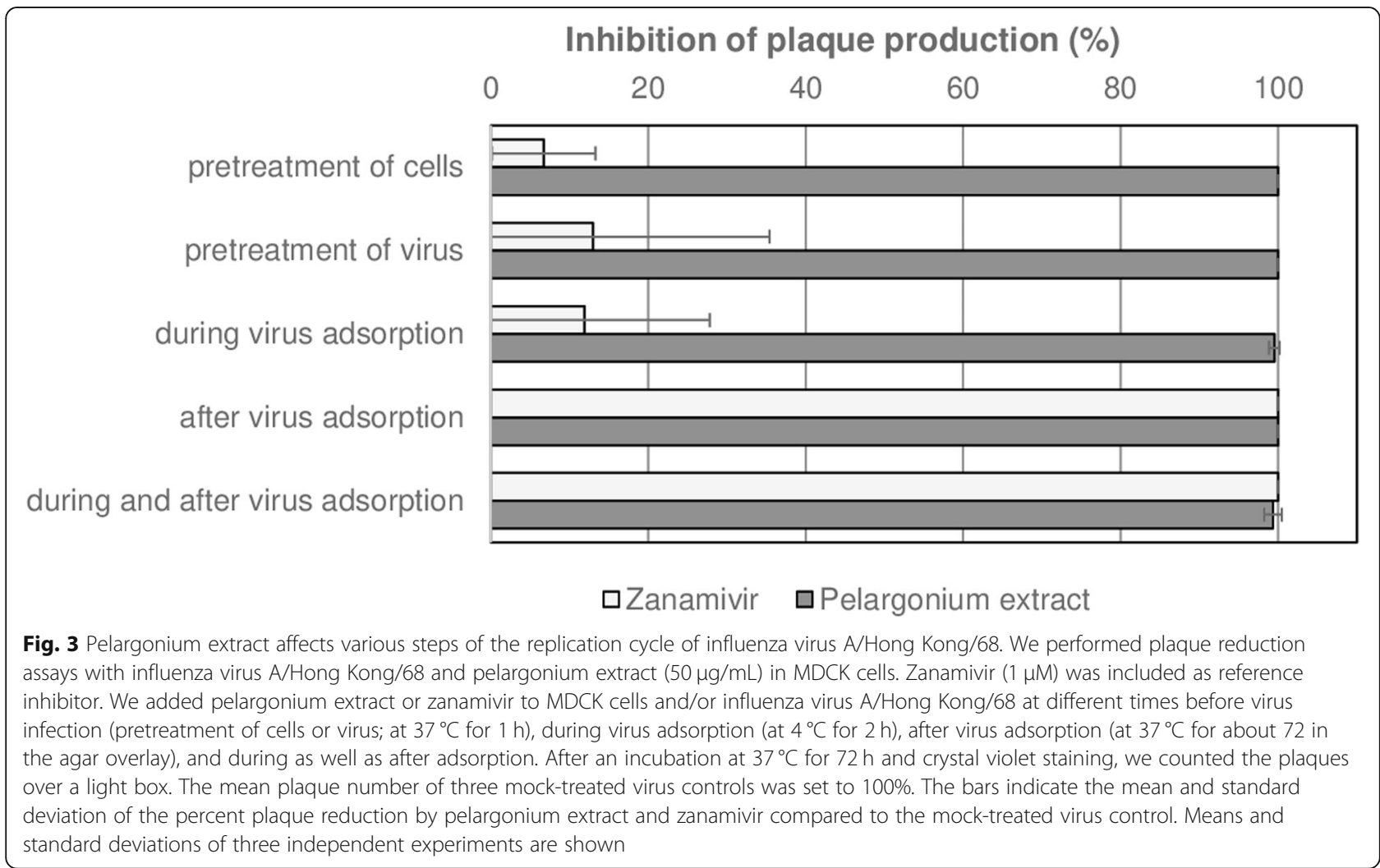




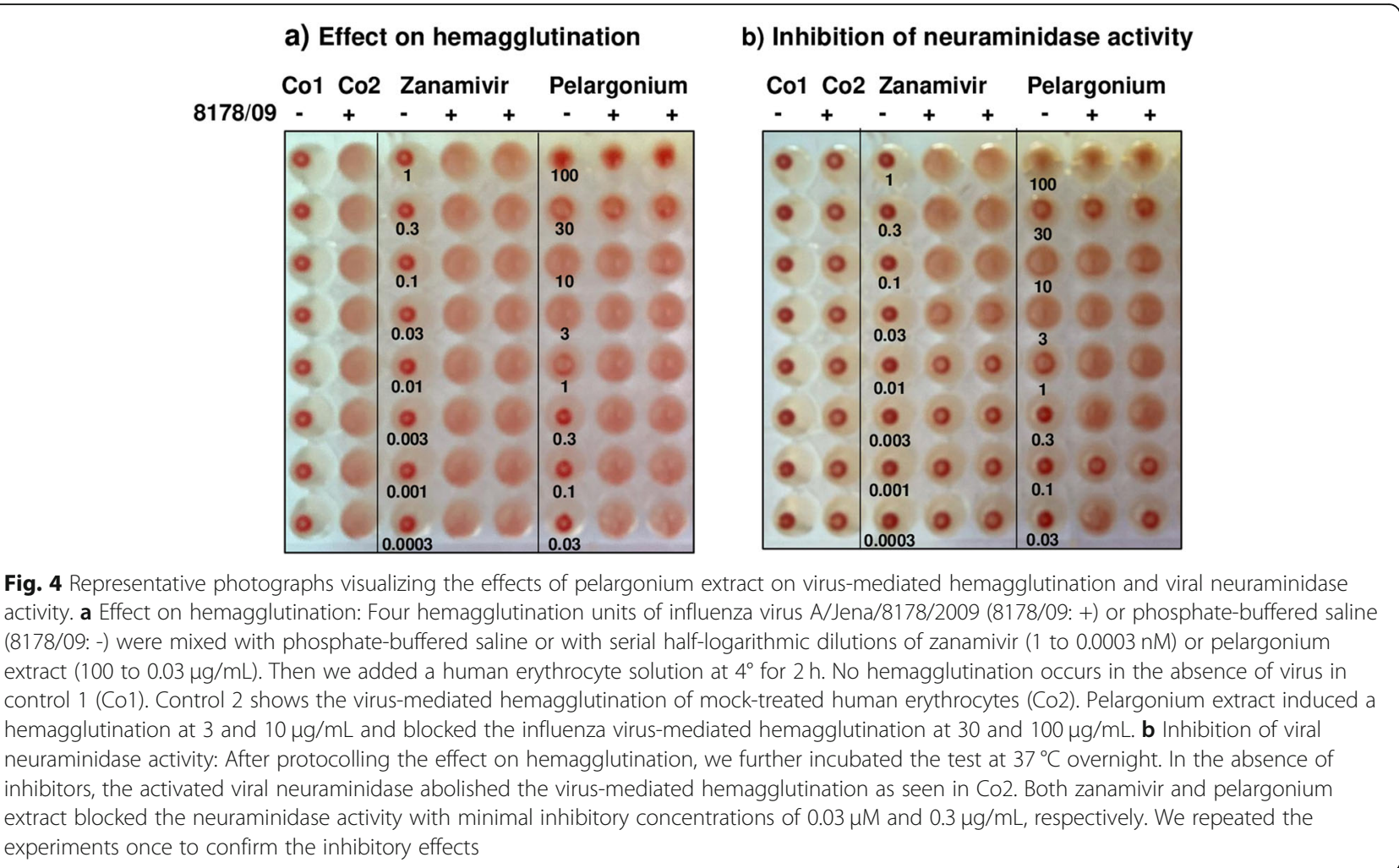

hemagglutination (Fig. 4a). Zanamivir neither mediated nor inhibited hemagglutination as expected (Fig. 4a).

The neuraminidase cleaved the bounds between the viral hemagglutinin and the sialic acid bounds of the mock-treated hemagglutination control during incubation at $37^{\circ} \mathrm{C}$ for $24 \mathrm{~h}$ causing abrogation of virusmediated hemagglutination in control 2 (Fig. 4b; Co2). Both zanamivir and pelargonium extract treatment blocked the cleavage activity of the viral neuraminidase (Fig. 4b). Hence, abrogation of hemagglutination did not occur. The minimal neuraminidase inhibitory concentration of zanamivir and pelargonium extract was $0.03 \mu \mathrm{M}$ and $0.3 \mu \mathrm{g} / \mathrm{mL}$, respectively. In conclusion, pelargonium extract interfered with influenza virus binding to its receptors (adsorption) as well as neuraminidase activity crucial for viral release and transmission.

\section{Discussion}

In the presents study, we compared the effect of 5 commonly used over-the-counter products for treatment of acute respiratory infections on the replication of 2 rhinoviruses and 2 influenza $A$ viruses under standardized experimental conditions (e. g. MOI, compound treatment, spectrophotometric readout, control compounds) in an in vitro setting. The previously reported antiviral activity of the control compounds pleconaril $[33,34]$ and zanamivir $[36,37]$ was fully confirmed here. The results indicate a distinct anti-influenza A virus potential of thyme and pelargonium extracts.

At non-cytotoxic concentrations, neither bromhexine nor its metabolite ambroxol $(0.0316-100 \mu \mathrm{M})$ exerted $\mathrm{a} \geq 50 \%$ CPE inhibition against the tested rhinoviruses and influenza A viruses in HeLa Ohio and MDCK cells, respectively, when added immediately before virus challenge to the cells. Ambroxol reaches a mean peak human plasma concentration of about $0.2 \mu \mathrm{M}$ [44], a concentration that was non-cytotoxic and did not act antiviral here. In contrast, a 3-day pretreatment of primary cultures of human tracheal epithelial cells with ambroxol at a concentration of at least $0.1 \mu \mathrm{M}$ reduced the titer of rhinovirus B14 in the supernatant in a concentration-dependent manner [24]. According to Yamaya et al., a 3-day pretreatment of the cells with ambroxol indirectly affected the rhinovirus B14 infection by reducing the virus receptor expression, the number of acidic endosomes, and the fluorescence intensity of the acidic endosomes compared to untreated or vehicletreated cells. The antiviral effect of ambroxol added immediately before virus inoculation was not studied by these authors. Therefore, it remains unclear whether the different study outcome is based on the different cells used, the pretreatment with ambroxol or both. To the best of our knowledge, there are no publications on the anti-influenza virus effect of ambroxol in vitro. In mouse airways influenza virus replication was indirectly 
suppressed by ambroxol-induced increase of the concentration of suppressors of viral replication, such as pulmonary surfactant, mucus protease inhibitor, and immunoglobulin A [25]. The absence of pulmonary surfactant, mucus protease inhibitor, and immunoglobulin A in vitro could explain the lack of anti-viral activity in in vitro experiments.

No antirhinoviral activity was found for the antioxidant molecule $\mathrm{N}$-acetylcysteine $(0.0316-100 \mu \mathrm{M})$ in the present study. There are no publications on the anti-rhinovirus effect of $\mathrm{N}$-acetylcysteine in vitro. The negative results obtained for influenza A viruses seem to be in contradiction with previous findings obtained with influenza A viruses in A549 cells $[27,28]$. However, this previously published anti-influenza virus activity was observed after treating A549 cells at much higher concentrations (10 and/or $15 \mathrm{mM}$ ), starting with a $1 \mathrm{~h}$ or $24 \mathrm{~h}$ pre-incubation period prior to virus infection. In striking contrast, the maximal plasma concentration following the application of 600 $\mathrm{mg} \mathrm{N}$-acetylcysteine is only about $16 \mu \mathrm{M}$ [45]. There are two reports on the protective effects (reduction of lethality and/or body weight loss) of $\mathrm{N}$-acetylcysteine $(0.2$ or $1 \mathrm{~g} / \mathrm{kg}$ body weight per day) in models of influenza infection in mice $[29,46]$. Both reports explain the observed protective effects by the antioxidant activity of $\mathrm{N}$-acetylcysteine attenuating pulmonary inflammation, which does not play a role in in vitro experiments. A third report did not confirm the protective effect of $\mathrm{N}$-acetylcysteine $(1 \mathrm{~g} / \mathrm{kg}$ body weight per day) on survival and the mean survival time in influenza A virus-infected mice [26].

The thyme extract was well tolerated in both HeLa and MDCK cells. It was inactive against rhinoviruses but, reduced the influenza A virus-induced cytopathic effect at non-cytotoxic dilutions $(0.03-0.33 \% \mathrm{v} / \mathrm{v})$ in a dosedependent manner. Thyme extract is also known to inhibit herpes simplex virus infections in vitro $[47,48]$ by inactivating the infectivity of the virus [48].

Pelargonium extract treatment did not inhibit the induction of CPE by rhinoviruses A2 and B14 in HeLa Ohio cells. However, it was shown to reduce rhinovirus A16 infection of human primary bronchial epithelial cells by down-regulating cell membrane docking proteins and up-regulating host defense proteins, as described recently [31]. Pelargonium extract exerted the best anti-influenza $\mathrm{A}$ virus activity with mean $\mathrm{IC}_{50}$ values of 7.80 and $11.67 \mu \mathrm{g} / \mathrm{mL}$ for the two influenza A virus strains tested (H1N1: Jena/8178 and H3N2: HK/ 69). These results assort well with data published for Pelargonium sidoides extract EPs 7630 and other influenza A virus strains of subtype $\mathrm{H} 1 \mathrm{~N} 1$ and $\mathrm{H} 3 \mathrm{~N} 2$ in MDCK cells elsewhere [30, 32]. The results of our timeof-addition assays show that the tested pelargonium extract interacts with the membrane of MDCK cells as well as with the influenza virus envelope blocking plaque production in MDCK cells. We also found an interaction between pelargonium extract and the membrane of human erythrocytes that mediated hemagglutination. Moreover, pelargonium extract impaired viral hemagglutination as well as neuraminidase activity as did $\mathrm{EPs}^{\circ} 7630$ [32]. Hence, pelargonium extract inhibits various steps of the influenza virus life cycle. Polyphenolic compounds, in particular oligomeric and polymeric proanthocyanidins based on gallocatechin and epigallocatechin moieties (prodelphinidins), represent the antiviral active compounds in $\mathrm{EPs}^{\circ} 7630$. The benefit of $\mathrm{EPs}^{\circ} 7630$ treatment was also demonstrated in a mouse model of influenza where the extract was administered by inhalation [32].

\section{Conclusions}

The results obtained in the present in vitro study suggest that the inhibition of influenza virus replication by thyme and pelargonium extract may contribute to the beneficial effects of these plant extracts on symptoms of acute respiratory infections.

\section{Abbreviations \\ $\mathrm{CC}_{50}$ : 50\% cytotoxic concentration; CPE : Cytopathic effect; $I_{50}: 50 \%$ inhibitory concentrations; MDCK: Madin Darby canine kidney; \\ MOI: Multiplicity of infection; SD: Standard deviation}

\section{Acknowledgements}

Not applicable.

\section{Authors' contributions}

CW analyzed the cytotoxicity and antirhinoviral activity of the test items in HeLa Ohio cells. KD performed the mechanism of action studies with pelargonium extract. MS designed the study, analyzed the cytotoxicity and anti-influenza virus activity of the test items in MDCK cells and wrote the manuscript. The authors read and approved the final manuscript.

\section{Funding}

This work was financially supported by Sanofi-Aventis Deutschland GmbH. No influence was taken on study design, analysis and interpretation of data. Open Access funding enabled and organized by Projekt DEAL.

\section{Availability of data and materials}

The datasets used and/or analyzed during the current study are available from the corresponding author on reasonable request.

Ethics approval and consent to participate

Not applicable.

\section{Consent for publication}

Not applicable.

\section{Competing interests}

The authors declare that they have no competing interest.

Received: 28 April 2020 Accepted: 2 December 2020

Published online: 23 December 2020

References

1. The top 10 causes of death. Home/Newsroom/Fact sheets/Detail: World Health Organisation; 2020 [updated 24 May 2018. Available from: http:// fmrglobalhealth.com/frame/top10.html]. 
2. Gonzales R, Sande MA. Uncomplicated acute bronchitis. Ann Intern Med 2000;133(12):981-91. https://doi.org/10.7326/0003-4819-133-12200012190-00014

3. Tang D, Comish P, Kang R. The hallmarks of covid-19 disease. PLoS Pathog. 2020;16(5):e1008536. https://doi.org/10.1371/journal.ppat.1008536.

4. Heikkinen T, Jarvinen A. The common cold. Lancet. 2003:361 (9351):51-9. https://doi.org/10.1016/S0140-6736(03)12162-9.

5. Taylor S, Lopez P, Weckx L, Borja-Tabora C, Ulloa-Gutierrez R, Lazcano-Ponce E, Kerdpanich A, Angel Rodriguez Weber M, Mascarenas de Los Santos A, Tinoco JC, Safadi MA, Lim FS, Hernandez-de Mezerville M, Faingezicht I, Cruz-Valdez A, Feng Y, Li P, Durviaux S, Haars G, Roy-Ghanta S, Vaughn DW, Nolan T. Respiratory viruses and influenza-like illness: Epidemiology and outcomes in children aged 6 months to 10 years in a multi-country population sample. J Inf Secur. 2017;74(1):29-41. https://doi.org/10.1016/j. jinf.2016.09.003.

6. Influenza (seasonal). Home/Newsroom/Fact sheets/Detail: World Health Organisation; 2020 [updated 6 November 2018. Available from: https:// www.who.int/en/news-room/fact-sheets/detail/influenza-(seasonal).

7. Egorova A, Ekins S, Schmidtke M, Makarov V. Back to the future: advances in development of broad-spectrum capsid-binding inhibitors of enteroviruses. Eur J Med Chem. 2019;178:606-22. https://doi.org/10. 1016/j.ejmech.2019.06.008.

8. Rollinger JM, Schmidtke M. The human rhinovirus: human-pathological impact, mechanisms of antirhinoviral agents, and strategies for their discovery. Med Res Rev. 2011;31(1):42-92. https://doi.org/10.1002/med. 20176.

9. Mittal A, Manjunath K, Ranjan RK, Kaushik S, Kumar S, Verma V. Covid-19 pandemic: insights into structure, function, and hace2 receptor recognition by sars-cov-2. PLoS Pathog. 2020;16(8):e1008762. https://doi.org/10.1371/ journal.ppat.1008762

10. Cataldi JR, O'Leary ST, Lindley MC, Hurley LP, Allison MA, Brtnikova M, Beaty $B L$, Crane LA, Kempe A. Survey of adult influenza vaccination practices and perspectives among us primary care providers (2016-2017 influenza season). J Gen Intern Med. 2019. https://doi.org/10.1007/s11606-019-05164-7.

11. Hagel S, Ludewig K, Moeser A, Baier M, Loffler B, Schleenvoigt B, Forstner C, Pletz MW. Characteristics and management of patients with influenza in a german hospital during the 2014/2015 influenza season. Infection. 2016; 44(5):667-72. https://doi.org/10.1007/s15010-016-0920-0.

12. Jorgensen P, Mereckiene J, Cotter S, Johansen K, Tsolova S, Brown C. How close are countries of the who european region to achieving the goal of vaccinating $75 \%$ of key risk groups against influenza? Results from national surveys on seasonal influenza vaccination programmes, 2008/2009 to 2014/ 2015. Vaccine. 2018;36(4):442-52. https://doi.org/10.1016/j.vaccine.2017.12.019.

13. Wang $Q$, Yue N, Zheng M, Wang D, Duan C, Yu X, Zhang X, Bao C, Jin H. Influenza vaccination coverage of population and the factors influencing influenza vaccination in mainland China: a meta-analysis. Vaccine. 2018; 36(48):7262-9. https://doi.org/10.1016/j.vaccine.2018.10.045.

14. Mifsud EJ, Hayden FG, Hurt AC. Antivirals targeting the polymerase complex of influenza viruses. Antivir Res. 2019;169:104545. https://doi.org/10.1016/j. antiviral.2019.104545.

15. Naesens $L$, Stevaert A, Vanderlinden E. Antiviral therapies on the horizon for influenza. Curr Opin Pharmacol. 2016;30:106-15. https://doi.org/10.1016/j. coph.2016.08.003.

16. Johnson KEE, Song T, Greenbaum B, Ghedin E. Getting the flu: 5 key facts about influenza virus evolution. PLoS Pathog. 2017;13(8):e1006450. https:// doi.org/10.1371/journal.ppat.1006450.

17. To J, Torres J. Viroporins in the influenza virus. Cells. 2019;8(7). https://doi. org/10.3390/cells8070654.

18. Hamoen M, Broekhuizen BD, Little P, Melbye H, Coenen S, Goossens H, Butler CC, Francis NA, Verheij TJ. Group Gcs. Medication use in european primary care patients with lower respiratory tract infection: an observational study. Br J Gen Pract. 2014;64(619):e81-91. https://doi.org/10.3399/ bjgp14X677130.

19. Scaglione F, Petrini O. Mucoactive agents in the therapy of upper respiratory airways infections: fair to describe them just as mucoactive? Clin Med Insights Ear Nose Throat. 2019;12:1179550618821930. https://doi.org/ 10.1177/1179550618821930.

20. Paleari D, Rossi GA, Nicolini G, Olivieri D. Ambroxol: a multifaceted molecule with additional therapeutic potentials in respiratory disorders of childhood. Expert Opin Drug Discovery. 2011;6(11):1203-14. https://doi.org/10.1517/ 17460441.2011 .629646
21. Agbabiaka TB, Guo R, Ernst E. Pelargonium sidoides for acute bronchitis: a systematic review and meta-analysis. Phytomedicine. 2008;15(5):378-85. https://doi.org/10.1016/j.phymed.2007.11.023.

22. Careddu D, Pettenazzo A. Pelargonium sidoides extract eps 7630: a review of its clinical efficacy and safety for treating acute respiratory tract infections in children. Int J Gen Med. 2018;11:91-8. https://doi.org/10. 2147/IJGM.S154198.

23. Salehi B, Mishra AP, Shukla I, Sharifi-Rad M, Contreras MDM, SeguraCarretero A, Fathi H, Nasrabadi NN, Kobarfard F, Sharifi-Rad J. Thymol, thyme, and other plant sources: health and potential uses. Phytother Res. 2018;32(9):1688-706. https://doi.org/10.1002/ptr.6109.

24. Yamaya M, Nishimura $H$, Nadine LK, Ota C, Kubo H, Nagatomi R. Ambroxol inhibits rhinovirus infection in primary cultures of human tracheal epithelial cells. Arch Pharm Res. 2014;37(4):520-9. https://doi.org/10. 1007/s12272-013-0210-7.

25. Yang B, Yao DF, Ohuchi M, Ide M, Yano M, Okumura Y, Kido H. Ambroxol suppresses influenza-virus proliferation in the mouse airway by increasing antiviral factor levels. Eur Respir J. 2002;19(5):952-8.

26. Garozzo A, Tempera G, Ungheri D, Timpanaro R, Castro A. N-acetylcysteine synergizes with oseltamivir in protecting mice from lethal influenza infection. Int J Immunopathol Pharmacol. 2007;20(2):349-54. https://doi.org/ 10.1177/039463200702000215.

27. Geiler J, Michaelis M, Naczk P, Leutz A, Langer K, Doerr HW, Cinatl J Jr. Nacetyl-I-cysteine (nac) inhibits virus replication and expression of proinflammatory molecules in a549 cells infected with highly pathogenic h5n1 influenza a virus. Biochem Pharmacol. 2010;79(3):413-20. https:// doi.org/10.1016/j.bcp.2009.08.025.

28. Mata M, Morcillo E, Gimeno C, Cortijo J. N-acetyl-I-cysteine (nac) inhibit mucin synthesis and pro-inflammatory mediators in alveolar type ii epithelial cells infected with influenza virus $a$ and $b$ and with respiratory syncytial virus (rsv). Biochem Pharmacol. 2011;82(5):548-55. https://doi.org/ 10.1016/j.bcp.2011.05.014.

29. Ungheri D, Pisani C, Sanson G, Bertani A, Schioppacassi G, Delgado R, Sironi $M$, Ghezzi P. Protective effect of $n$-acetylcysteine in a model of influenza infection in mice. Int J Immunopathol Pharmacol. 2000;13(3) $123-8$.

30. Michaelis M, Doerr HW, Cinatl J Jr. Investigation of the influence of eps(r) 7630 , a herbal drug preparation from pelargonium sidoides, on replication of a broad panel of respiratory viruses. Phytomedicine. 2011;18(5):384-6. https://doi.org/10.1016/j.phymed.2010.09.008.

31. Roth M, Fang L, Stolz D, Tamm M. Pelargonium sidoides radix extract eps 7630 reduces rhinovirus infection through modulation of viral binding proteins on human bronchial epithelial cells. PLoS One. 2019;14(2): e0210702. https://doi.org/10.1371/journal.pone.0210702.

32. Theisen LL, Muller CP. Eps(r) 7630 (umckaloabo(r)), an extract from pelargonium sidoides roots, exerts anti-influenza virus activity in vitro and in vivo. Antivir Res. 2012;94(2):147-56. https://doi.org/10.1016/j. antiviral.2012.03.006

33. Ledford RM, Patel NR, Demenczuk TM, Watanyar A, Herbertz T, Collett MS, Pevear DC. Vp1 sequencing of all human rhinovirus serotypes: insights into genus phylogeny and susceptibility to antiviral capsid-binding compounds. J Virol. 2004;78(7):3663-74.

34. Makarov VA, Braun H, Richter M, Riabova OB, Kirchmair J, Kazakova ES, Seidel N, Wutzler P, Schmidtke M. Pyrazolopyrimidines: potent inhibitors targeting the capsid of rhino- and enteroviruses. ChemMedChem. 2015; 10(10):1629-34. https://doi.org/10.1002/cmdc.201500304.

35. Grienke U, Schmidtke M, von Grafenstein S, Kirchmair J, Liedl KR, Rollinger JM. Influenza neuraminidase: a druggable target for natural products. Nat Prod Rep. 2012;29(1):11-36. https://doi.org/10.1039/c1np00053e.

36. Schade D, Kotthaus J, Riebling L, Kotthaus J, Muller-Fielitz H, Raasch W, Hoffmann A, Schmidtke M, Clement B. Zanamivir amidoxime- and nhydroxyguanidine-based prodrug approaches to tackle poor oral bioavailability. J Pharm Sci. 2015;104(9):3208-19. https://doi.org/10.1002/jps.24508.

37. Walther E, Xu Z, Richter M, Kirchmair J, Grienke U, Rollinger JM, Krumbholz A, Saluz HP, Pfister W, Sauerbrei A, Schmidtke M. Dual acting neuraminidase inhibitors open new opportunities to disrupt the lethal synergism between streptococcus pneumoniae and influenza virus. Front Microbiol. 2016;7:357. https://doi.org/10.3389/fmicb.2016.00357.

38. Grienke U, Mair CE, Kirchmair J, Schmidtke M, Rollinger JM. Discovery of bioactive natural products for the treatment of acute respiratory infections - 
an integrated approach. Planta Med. 2018;84(9-10):684-95. https://doi.org/ 10.1055/a-0590-5153.

39. Schmidtke M, Schnittler U, Jahn B, Dahse H, Stelzner A. A rapid assay for evaluation of antiviral activity against coxsackie virus b3, influenza virus $a$, and herpes simplex virus type 1.J Virol Methods. 2001;95(1-2):133-43.

40. Pauwels R, Balzarini J, Baba M, Snoeck R, Schols D, Herdewijn P, Desmyter J, De Clercq E. Rapid and automated tetrazolium-based colorimetric assay for the detection of anti-hiv compounds. J Virol Methods. 1988;20(4):309-21.

41. Wald J, Pasin M, Richter M, Walther C, Mathai N, Kirchmair J, Makarov VA Goessweiner-Mohr N, Marlovits TC, Zanella I, Real-Hohn A, Verdaguer N, Blaas D, Schmidtke M. Cryo-em structure of pleconaril-resistant rhinovirus-b5 complexed to the antiviral obr-5-340 reveals unexpected binding site. Proc Natl Acad Sci U S A. 2019;116(38):19109-15. https://doi.org/10.1073/pnas. 1904732116.

42. Kaufmann L, Syedbasha M, Vogt D, Hollenstein Y, Hartmann J, Linnik JE, Egli A. An optimized hemagglutination inhibition (hi) assay to quantify influenzaspecific antibody titers. J Vis Exp. 2017;130. https://doi.org/10.3791/55833.

43. Richter M, Schumann L, Walther E, Hoffmann A, Braun H, Grienke U, Rollinger JM, von Grafenstein S, Liedl KR, Kirchmair J, Wutzler P, Sauerbrei A, Schmidtke M. Complementary assays helping to overcome challenges for identifying neuraminidase inhibitors. Futur Virol. 2015;10(2):77-88. https:// doi.org/10.2217/Fvl.14.97.

44. Su F, Wang F, Gao W, Li H. Determination of ambroxol in human plasma by high performance liquid chromatography-electrospray ionization mass spectrometry (hplc-ms/esi). J Chromatogr B Anal Technol Biomed Life Sci. 2007;853(1-2):364-8. https://doi.org/10.1016/j.jchromb.2007.03.015.

45. Borgstrom L, Kagedal B. Dose dependent pharmacokinetics of $n$ acetylcysteine after oral dosing to man. Biopharm Drug Dispos. 1990;11(2): $131-6$.

46. Zhang RH, Li CH, Wang $C L, X u M J$, Xu T, Wei D, Liu BJ, Wang GH, Tian SF. Nacetyl-I-cystine (nac) protects against h9n2 swine influenza virus-induced acute lung injury. Int Immunopharmacol. 2014;22(1):1-8. https://doi.org/10. 1016/j.intimp.2014.06.013.

47. Rajbhandari M, Mentel R, Jha PK, Chaudhary RP, Bhattarai S, Gewali MB, Karmacharya N, Hipper M, Lindequist U. Antiviral activity of some plants used in nepalese traditional medicine. Evid Based Complement Alternat Med. 2009;6(4):517-22. https://doi.org/10.1093/ecam/nem156.

48. Toujani MM, Ritta M, Civra A, Genovese S, Epifano F, Ghram A, Lembo D, Donalisio M. Inhibition of hsv-2 infection by pure compounds from thymus capitatus extract in vitro. Phytother Res. 2018;32(8):1555-63. https://doi.org/ 10.1002/ptr.6084

\section{Publisher's Note}

Springer Nature remains neutral with regard to jurisdictional claims in published maps and institutional affiliations.

Ready to submit your research? Choose BMC and benefit from:

- fast, convenient online submission

- thorough peer review by experienced researchers in your field

- rapid publication on acceptance

- support for research data, including large and complex data types

- gold Open Access which fosters wider collaboration and increased citations

- maximum visibility for your research: over $100 \mathrm{M}$ website views per year

At $\mathrm{BMC}$, research is always in progress.

Learn more biomedcentral.com/submissions 